\section{China leads the way on renewables}

The boom in renewable energy being led by China, India, Europe, the United States and Japan is key to the mitigation of carbon emissions (see Nature 507, 300-302; 2014). Last year marked an important turning point for China's renewable-energy revolution in particular, with water, wind and solar sources accounting for more electricitygenerating capacity (59\%) than new fossil-fuel or nuclear facilities (41\%; see go.nature.com/z6job5).

China generated 5,322 billion kilowatt-hours of electricity, of which $74 \%$ came from coalfired power stations (a marked improvement on the $80 \%$ mentioned by some researchers; see D. Helm Nature 491, $663-665 ; 2012)$. The balance was contributed primarily by hydropower $(17 \%)$, wind $(2.6 \%)$, nuclear $(2.1 \%)$ and solar sources $(0.16 \%)$. Water, wind and solar energy therefore account for one-fifth of electricity generated in China - anticipating by two years the target that the country set for 2015.

John A. Mathews Macquarie University, Sydney, Australia. john.mathews@mgsm.edu.au Hao Tan University of Newcastle, Callaghan, New South Wales, Australia.

\section{Vanadium batteries will be cost-effective}

Vanadium flow batteries are an attractive commercial proposition because they are safe and environmentally friendly, use recyclable electrolytes, have a long cycle life (around 13,000 cycles) and last for more than 15 years. Their cost is not as prohibitive as believed (Nature 507, 26-28; 2014).

You quote my estimated cost of US $\$ 1,000$ per kilowatthour, which is indeed high, but this applies to the world's largest vanadium flow battery system and includes materials, manufacture, the control system, transportation, installation and maintenance. The cost of a system that is one-fifth of this size is $\$ 600$ per kilowatt-hour, which is expected to drop to $\$ 400$ per kilowatt-hour within the next 2-3 years.

After two years of innovation and development, the current density of vanadium flow battery stacks from the Rongke Power company in Dalian, China, has risen from 80 to 120 milliamps per square centimetre.

Although the cost of vanadium itself is relatively high, these flow batteries hold promise as large-scale energystorage devices.

Huamin Zhang Dalian Institute of Chemical Physics, Chinese Academy of Sciences, Dalian, China.

zhanghm@dicp.ac.cn

\section{A trading scheme to reduce false results}

Cap-and-trade systems have proved useful in cutting pollutants such as sulphur dioxide, nitrogen oxides and lead additives in petrol (see L. H. Goulder J. Econ. Perspect. 27, 87-102; 2013). We suggest that they could also be applied to reduce pollution of the scientific literature with irreproducible results (see go.nature.com/ huhbyr).

Companies do not have to deal with the social costs of pollution, so there is little incentive for them to reduce it. Likewise, researchers do not have to face the cost of publishing their own unverifiable results (most of which could have been prevented). That cost is borne by the scientific community and the public - for instance, in subsequent research inspired by false positives, which can lead to badly designed policies.

Cap-and-trade systems force excessive polluters to purchase permits. Initially, institutions could receive 5 free permits per
100 published results, reflecting the widely accepted ideal of a $5 \%$ false-positive production rate. It would then be necessary to buy extra permits from other institutions should they 'emit' significantly more false positives that this (irrespective of whether these were honest or deliberate errors).

Institutions that successfully reduce false positives in their research output could then sell off their surplus permits to other institutions that have exceeded their allocation. This flexibility would create incentives for researchers to find innovative ways to reduce false positives. Michael E. McCullough, David L. Kelly University of Miami, Coral Gables, Florida, USA. mikem@miami.edu

\section{Mouse already being charted gene by gene}

Steve Perrin's call to make mouse studies work (Nature 507, 423-425; 2014) resonates with the goals and practices of the International Mouse Phenotyping Consortium (see www.impc.org).

The consortium's ten-year goal is to generate a 'knockout' mutant for every gene in the mouse genome in an effort to characterize the phenotype that each gene confers (S. D. Brown and M. W. Moore Mamm. Genome 23, 632-640; 2012). Standardized phenotyping protocols (www.impc.org/ impress) have been carefully designed and validated by the consortium to provide robust, reproducible information, and a statistics advisory group reviews the data and procedures.

All mutant lines and phenotype data are freely available, including summary data for a cohort compared with multiple controls. To overcome any potential issue of publication bias, we include all negative results as well as positive ones.

Careful evaluation of mouse models and their standardized phenotypes, as well as confidence in the reproducibility and validity of summary and individual phenotypic data, is critical to fostering successful preclinical studies.

Steve Brown ${ }^{\star}$ International Mouse Phenotyping Consortium; MRC Harwell, Didcot, UK.

s.brown@har.mrc.ac.uk ${ }^{\star}$ On behalf of 22 co-signatories; see go.nature.com/iu6xuffor full list.

\section{Experimentation is science's lifeblood}

No one can become a genuine scientist without doing practical work, as John Baruch points out (see Nature 507, 141; 2014) whether it is at the lab bench or desk. But it is not the successful experiments that count so much as the frustrations inflicted by those that fail.

It is the embarrassment of a statistical analysis that reveals inadvertent data-input errors; it is tearing one's hair out debugging a program that once worked well; it is learning that "nature cannot be fooled" (as physicist Richard Feynman warned).

This experience of failure and error is unique to science. In the humanities, a student learns from mistakes such as not remembering to use specialist vocabulary, failing to put forward established arguments or not engaging in self-promotion before and after seminars. Practical science demonstrates that doing science involves more than just picking up such tricks. John Skoyles University College London, UK. j.skoyles@ucl.ac.uk

CONTRIBUTIONS Correspondence may be sent to correspondence@ nature.com after consulting the author guidelines at http://go.nature.com/ cmchno. 